\title{
Introduction of the 2007 American Pediatric Society John Howland Award Recipient, Ralph D. Feigin, M.D. Tales of a Modern Day Super Hero
}

\author{
GALI J. DEMMLER \\ Department of Pediatrics, Baylor College of Medicine, Houston, TX 77030
}

$I^{\prime}$ $\mathrm{t}$ is a bittersweet honor to stand before you this morning and introduce Dr. Ralph D. Feigin (Fig. 1), the 2007 Howland Award Recipient. It is an honor, because Dr. Feigin's dynamic career of distinguished service is legendary; it is bittersweet because the honor would not be mine had we not lost our beloved Norm. Dr. Norman Siegel was the first voice, joined by a chorus of 38 supporters, to nominate Dr. Feigin for this prestigious award. When Norm died, tragically, while attending our annual meeting last year, I, along with over a dozen other vociferous voices joined the "original crew" and carried the torch to the finishing line. And so here we are.

Ralph Feigin was born on April 3, 1938 in New York City. He attended Franklin School in Manhattan, where he played basketball and other sports, and met a girl (Judith S. Zobel). He graduated AOA from Columbia College in New York in 1958, married that girl in 1960 (Figure S1, online), and received his M.D. from Boston University School of Medicine in 1962. He completed his pediatric training as Chief Resident in Boston in 1968. For those of you who do math in their head, rest assured, it did not take Ralph Feigin 6 years to finish pediatric residency! For two of those years, a line on his curriculum vitae simply reads: 1965 to 1967 - Military Service Research Assignment - United States Army Research Institute of Infectious Diseases, Frederick, Maryland.

During those 2 years Dr. Feigin published numerous articles, including many on the circadian periodicity of amino acid metabolism during infection What his curriculum vitae does not confirm, however, is the rumor that one of his many laboratory experiments went, shall we say, awry, and when the bioradioactive dust settled, Dr. Ralph D. Feigin emerged a changed man, with endless bounding energy, a photographic memory, keen vision and insight, and superhuman abilities to think, move, and multitask at "rocket speed." He was not able to publish the results of this "failed" experiment, because it

Received June 6, 2007; accepted June 8, 2007

Correspondence: Gail J. Demmler, M.D., Texas Children's Hospital, Mail Code MC3-2371, 6621 Fannin Street, Houston, TX 77030; e-mail: gjdemmle@ texaschildrenshospital.org

Presented at the 2007 Annual Meeting of the Pediatric Academic Societies, Toronto, Ontario, Canada.

Supplemental material available online at www.pedresearch.org didn't really happen. However, he did go on to successfully publish over 500 other scientific and scholarly publications.

When Dr. Ralph Feigin, government scientist, completed his experiments, and "came in from the cold," he was recruited by Dr. Phillip Dodge and went to, where else, St. Louis! (Figure S2, online). In St. Louis, Dr. Feigin established one of the finest infectious diseases sections in the country. Obviously productive, and uniquely collaborative, they joined forces with Dr. Jim Cherry and his team at a neighboring institution, and published just two papers shy of 100 manuscripts in less than 10 years, many of which were landmark contributions in the pathogenesis, antibiotic management, and outcome of serious bacterial infections. They also dabbled in leptospirosis, and ventured into viruses. Their most impressive viral adventure chronicled a measles epidemic in St. Louis, where they comprehensively collected clinical and epidemiologic data from numerous medical and community sources on over 15,000 children and performed in depth laboratory and serologic studies on hundreds more (Figure S3). They accomplished amazing, some say impossible feats of pediatric research, especially when you consider there were no computers, no Internet, no cell phones, and no fax machines. All that was needed, Dr. Jim Cherry said, was teamwork, peppered with a little of Ralph Feigin's enthusiasm! Or, were they aided by his emerging superhuman powers?

In St. Louis, in 1976, the dynamic duo of Feigin and Cherry continued their enduring superhero collaboration by producing The Textbook of Pediatric Infectious Diseases, now a two volume set of over 3,000 pages of authoritative text that is currently in its sixth edition of production (Figure S4, online). Ralph Feigin has also co-edited two additional major textbooks (Principles and Practice of Pediatrics, now in its fourth edition, and the living electronic document Up-To-Date, Inc Pediatrics), and has served on six Editorial Boards. According to Dr. Robert Haggerty, "He has been one of the most accomplished editors in Pediatrics."

In St. Louis, Ralph Feigin also refined his superhuman teaching skills. His legendary "Feigin Rounds" were born here. Dr. Larry Shapiro once told us "As often as we were able, no matter what service we were on, students and residents would sneak away from their duties, and from their 


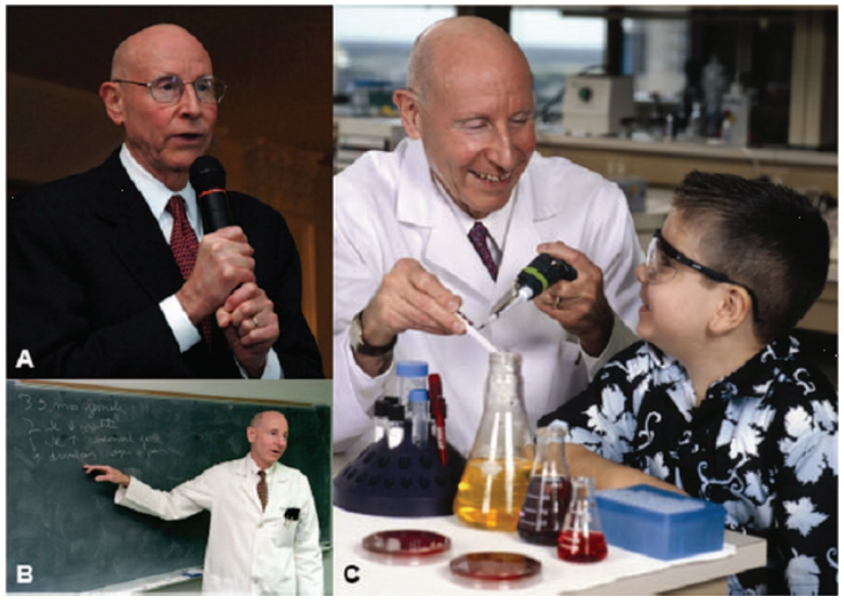

Figure 1. (A) Dr. Feigin speaking at a celebration of the $10^{\text {th }}$ Anniversary of the Texas Children's Pediatric Associates. (B) Dr. Feigin teaching residents and medical students in 1997 during his weekly "Feigin Rounds" at Texas Children's Hospital in Houston, Texas. (C) Dr. Feigin teaching Mark Sepulveda, a young member of the next generation of scientists. All photographs courtesy of Texas Children's Hospital.

spouses and significant others, to attend Saturday morning Feigin Rounds. The learning experience was unparalleled. He received so many teaching awards that they began to exclude Ralph from the competition." Ralph Feigin would go on to repeat history at Baylor College of Medicine, by winning so many Outstanding Teacher Awards that he was, once again, excluded from the competition, and elected to the Teaching Hall of Fame (Fig. 1B).

Dr. Feigin's list of prestigious national teaching awards, honors, and visiting professorships is indeed impressive. But I believe it is his weekly ritual of "Feigin Rounds," with the students and residents he cherishes the most, and from which he gains and sustains, at least some, of his superhuman energy and strength. They are truly a precious gift Dr. Feigin gives to us, no matter how busy he is, and they are a living testament of this man's real and personal commitment to pediatric education.

Not on his curriculum vitae, however, is a special award from the second year medical students at Washington University in St. Louis for his enthusiastic teaching of infectious diseases. "It was a white laboratory jacket", Dr. Morey Haymond told us, "carefully decorated with the emblazoned logo of a rocket ship. Across the back was written "Ralph the Rocket'." Our super human, super hero's name was finally unveiled! However, some say, his super hero identity was also in danger of discovery, so he left St. Louis and rocketed to Texas, and assumed a new identity (Figure S5, online). But Dr. Feigin told us he left St. Louis to follow a vision of building a preeminent children's hospital and a world-class department of pediatrics. "When I came to Houston in 1977," Ralph Feigin was quoted as saying, "it was my intent to participate in building a preeminent children's hospital and a world class department of pediatrics. Some place I thought could be the best place in the world. I tried to carry out a vision" (Figure S6, online).

So, in 1977, the Space City of Houston welcomed another Rocket. At the age of 39, Ralph Feigin assumed dual duties as the Chair of Pediatrics for Baylor College of Medicine and as the Physician-in-Chief at Texas Children's Hospital. Texas Children's Hospital opened in 1954, with 106 beds dedicated to specialized pediatric care, and with a resolution to provide medical care and attention to any child in Texas who was in need. The same year, the Department of Pediatrics at Baylor College of Medicine had 13 faculty members. When Dr. Feigin arrived, the Department had 43 faculty members, and the hospital had 7 floors, 234 beds, and a huge debt! In fact, some say the hospital, in its valiant efforts to provide treatment for all who needed what it had, was hemorrhaging cash and suffering from a potentially fatal financial crisis. But Ralph Feigin was undaunted, and stated: "The opportunities here are phenomenal, with virtually unlimited potential for growth that doesn't exist anywhere else in the world, and I'm excited to be here" (Figure S7, online).

Our super hero immediately applied pressure to the hemorrhage and implemented an integrated, five-year plan for financial well being, while simultaneously achieving threepronged excellence in education, research and patient care. Armed with clarity of purpose, the velocity of "The Rocket's" vision accelerated. He recruited people who shared the vision, participated in it, and followed it through. The five-year plan was completed, "Feigin style," in 9 months! And Ralph Feigin began to predict the future by creating it.

For now 30 wonderful years, Ralph Feigin has served as Chair and Chief. For two of these years, he also served as CEO of Texas Children's Hospital, until the position was assumed by co-visionary, Mr. Mark Wallace, and for another 7 of those years, he served as President and CEO of Baylor College of Medicine. Our Department of Pediatrics has grown to almost 500 faculty members. Each year, we teach and oversee hundreds of house staff and fellows, we raise hundreds of millions of dollars for research, and we provide care to thousands of suffering children. Through a continuous stream of capital campaigns that have raised billions of dollars, the brick and mortar of Texas Children's Hospital has grown to include four massive towers, including one, currently undergoing expansion, which bears the Feigin name (Figure S8, online), that are all dedicated to three pronged excellence in teaching, research, and patient care. And the hospital, now financially secure, with close to a two billion dollar endowment, continues to expand, and is currently building a Neurologic Research Institute, a Maternity/Neonatal Center, and a West Houston hospital campus.

Even with still so much work to do at home, Ralph Feigin, with his "immutable advocacy for children" (according to Dr. Caroline Breese Hall), serves in leadership roles in over 100 local, regional and national committees, and professional societies, persuading government officials of all ranks, wherever he can find them (Figure S9, online), to help children not only in our own community, but children in all parts of the world. All the while never interrupting the weekly ritual of his beloved "Feigin Rounds." All the while also quietly continuing service to our country as Consultant to the Surgeon General of the United States Army, on an issue he started over 40 years ago, defense of the United States against biowarfare. All the while, "despite his boundless energy, always being a 
gentleman, sensitive to the needs of those about him" (according to Dr. Phillip Dodge), "radiating not only wisdom and exceptional skills, but also compassion, warmth, gentleness and kindness" (according to Dr. Melvin Grumbach), "doing so with ease and never embarrassing those of us who move at a more modest pace" (according to Dr. Samuel Katz), and forever reminding us, that in his heart, "people will always come first" (RDF) (Figure 1C).

In closing, I recall one summer evening, when I sat across from Dr. Feigin at a backyard barbecue held at the home of Dr. Sheldon Kaplan. In the midst of Dr. Feigin's chatter about his plans for yet another capital fund drive, I asked him if he ever took a breath, to appreciate everything he had already accomplished, before embarking on yet another project. He leaned forward, and said, with a hint of urgency in his voice, "I never stop and I never look back. I always keep moving, and I always keep looking forward."

Ralph Feigin, you dream the impossible dream, and then make it reality (Fig. 1A). Your contributions and accomplishments have not only met, not only exceeded, they have, through your visionary and inspirational leadership, amplified a million fold, the objectives of our society. For all that you have done, for all that you are doing now, and for all you no doubt will do in the future for the children of the world, we ask you to pause, for just one, brief shining moment, and come forward to accept the 2007 John Howland Award (Figure S10, online). 